\title{
Milk vitamin $D$ in relation to the 'adequate intake' for 0-6-month-old infants: a study in lactating women with different cultural backgrounds, living at different latitudes
}

\author{
Eline Stoutjesdijk ${ }^{1 *}$, Anne Schaafsma ${ }^{2}$, Nguyen V. Nhien ${ }^{3}$, Geok Lin Khor ${ }^{4}$, Ido P. Kema ${ }^{1}$, \\ Bruce W. Hollis ${ }^{5}$, D. A. Janneke Dijck-Brouwer ${ }^{1}$ and Frits A. J. Muskiet ${ }^{1}$ \\ ${ }^{1}$ Laboratory Medicine, University Medical Center Groningen and University of Groningen, PO Box 30.001, 9700 RB \\ Groningen, The Netherlands \\ ${ }^{2}$ FrieslandCampina, PO Box 1551, 3800 BN Amersfoort, The Netherlands \\ ${ }^{3}$ National Institute of Food Control, 65 - Pham Than Duat - Cau Giay, Hanoi, Vietnam \\ ${ }^{4}$ International Medical University, No. 126, Jalan Jalil Perkasa 19, Bukit Jalil, 57000, Kuala Lumpur, Malaysia \\ ${ }^{5}$ Medical University of South Carolina, 171 Ashley Avenue, Charleston, SC 29425, USA \\ (Final revision received 2 March 2017 - Submitted 11 September 2017 - Accepted 25 September 2017-First published online 6 November 2017)
}

\section{Abstract}

Breast-fed infants are susceptible to vitamin D deficiency rickets. The current vitamin D 'adequate intake' (AI) for 0-6-month-old infants is $10 \mu \mathrm{g} / \mathrm{d}$, corresponding with a human milk antirachitic activity (ARA) of $513 \mathrm{IU} / \mathrm{l}$. We were particularly interested to see whether milk ARA of mothers with lifetime abundant sunlight exposure reaches the AI. We measured milk ARA of lactating mothers with different cultural backgrounds, living at different latitudes. Mature milk was derived from 181 lactating women in the Netherlands, Curaçao, Vietnam, Malaysia and Tanzania. Milk ARA and plasma 25-hydroxyvitamin D $(25(\mathrm{OH}) \mathrm{D})$ were analysed by liquid-chromatography-MS/MS; milk fatty acids were analysed by GC-flame ionisation detector (FID). None of the mothers reached the milk vitamin D AI. Milk ARA ( $n$; median; range) were as follows: Netherlands ( $n$ 9; 46 IU/1; 3-51), Curaçao ( $n$ 10; 31 IU/1; 5-113), Vietnam: Halong Bay ( $n$ 20; 58 IU/1; 23-110), Phu Tho ( $n$ 22; 28 IU/1; 1-62), Tien Giang ( $n$ 20; 63 IU/1; 26-247), Ho-Chi-Minh-City ( $n$ 18; 49 IU/1; 24-116), Hanoi ( $n$ 21; 37 IU/1; 11-118), Malaysia-Kuala Lumpur ( $n$ 20; 14 IU/1; $1-46)$ and Tanzania-Ukerewe ( $n$ 21; $77 \mathrm{IU} / 1 ; 12-232)$ and Maasai $(n$ 20; $88 \mathrm{IU} / 1 ; 43-189)$. We collected blood samples of these lactating women in Curaçao, Vietnam and from Tanzania-Ukerewe, and found that 33.3\% had plasma 25(OH)D levels between 80 and $249 \cdot 9 \mathrm{nmol} / 1$, $47 \cdot 3 \%$ between 50 and $79.9 \mathrm{nmol} / 1$ and $19.4 \%$ between 25 and $49.9 \mathrm{nmol} / 1$. Milk ARA correlated positively with maternal plasma 25(OH)D (range 27-132 nmol/1, $r 0.40)$ and milk EPA+DHA $(0 \cdot 1-3 \cdot 1 \mathrm{~g} \%, r 0 \cdot 20)$, and negatively with latitude $\left(2^{\circ} \mathrm{S}-53^{\circ} \mathrm{N}, r-0 \cdot 21\right)$. Milk ARA of mothers with lifetime abundant sunlight exposure is not even close to the vitamin D AI for 0-6-month-old infants. Our data may point at the importance of adequate fetal vitamin D stores.

Key words: Adequate intake: Antirachitic activity: Breast milk: Fish oil: Vitamin D

Exclusively breast-fed infants are susceptible to vitamin D deficiency rickets ${ }^{(1)}$. Low infant vitamin D status predicts low bone mass at 9 years $^{(2)}$. Furthermore, vitamin D deficiency is associated with autoimmune disease ${ }^{(3)}$ and acute lower respiratory tract infections ${ }^{(4,5)}$ In addition, vitamin $\mathrm{D}$ deficiency in the 1st month of fetal life may affect brain cell growth and differentiation and may thereby contribute to psychiatric diseases, such as autism and schizophrenia, at a later age ${ }^{(6)}$.

The vitamin D status of exclusively breast-fed infants depends on sunlight exposure, vitamin D stores at birth and the breast milk vitamin $\mathrm{D}$ output ${ }^{(7)}$. Breast milk contains both parent vitamin $\mathrm{D}$ and 25-hydroxyvitamin D (25(OH)D). These are usually summed to the so-called antirachitic activity (ARA). Breast milk ARA in Western mothers ranges from 8 to $332 \mathrm{IU} / \mathrm{l}^{(8-10)}$. The current vitamin $\mathrm{D}$ adequate intake (AI) of the Institute of Medicine (IOM) for 0-6-month-old infants is $10 \mu \mathrm{g} / \mathrm{d}^{(11)}$, which translates to an ARA of $513 \mathrm{IU} / 1$ in mature breast milk at an average milk consumption of $780 \mathrm{ml} / \mathrm{d}^{(12)}$. The AI of the IOM is based on limited data from Finland, South Africa and the USA, showing that $10 \mu \mathrm{g} / \mathrm{d}$ maintains infant serum $25(\mathrm{OH}) \mathrm{D}$ at $30-50 \mathrm{nmol} / \mathrm{l}$ in the first postnatal year and thereby supports normal bone accretion ${ }^{(11)}$. In view of the low breast milk vitamin $\mathrm{D}$ and the current advice to protect 0-6-month-old infants from direct sunlight exposure ${ }^{(13)}$, the American Academy of Pediatrics advices supplementation of all breast-fed infants with $10 \mu \mathrm{g}$ vitamin D daily ${ }^{(14)}$. Most guidelines in European countries are in line with this advice ${ }^{(15)}$.

The determinants of milk ARA are maternal vitamin D intake from the diet and supplements, vitamin D stores and sunlight

Abbreviations: 25(OH)D, 25-hydroxyvitamin D; AI, adequate intake; ARA, antirachitic activity; DBP, vitamin D binding protein; IOM, Institute of Medicine; PP, postpartum.

* Corresponding author: E. Stoutjesdijk, email e.stoutjesdijk@umcg.nl 
exposure. Vitamin D intakes from dietary sources are unlikely to influence milk vitamin D to a great extent. In the Netherlands, the median dietary vitamin D intake of 19-30-year-old Dutch women is $2.6 \mu \mathrm{g} / \mathrm{d}$. This intake is only slightly higher than the Dutch AI of $2.5 \mu \mathrm{g} / \mathrm{d}^{(16)}$, and is remote from the daily requirement of $10 \mu \mathrm{g} / \mathrm{d}^{(17)}$. Mushrooms exposed to UV-B harbour highest amounts of vitamin $\mathrm{D}_{2}$, whereas fish like halibut, carp, mackerel, eel and salmon contain highest amounts of vitamin $\mathrm{D}_{3}{ }^{(18)}$. Supplementation of pregnant and/or lactating women by up to $50 \mu \mathrm{g} / \mathrm{d}$ increases milk with only $23-35 \mathrm{IU} / \mathrm{l}^{(9,19-21)}$. Little is known on the relative contribution of maternal vitamin D stores on milk ARA ${ }^{(8)}$. Ala-Houhala et al. ${ }^{(9)}$ demonstrated seasonal differences in milk ARA in lactating Finnish women (mean ARA $124 \mathrm{IU} / 1$ in summer; $14 \mathrm{IU} / 1$ in winter) that are driven by the more abundant UV-B radiation in summer.

From an evolutionary point of view, it is puzzling why milk ARA is so low that infants need to be supplemented with vitamin D. To our knowledge, there are no data available on milk ARA of women with lifetime abundant sunlight exposure causing a high vitamin D status. We were interested to see whether milk vitamin D of mothers with lifetime abundant sunlight exposure reaches the current AI for 0-6-month-old infants. In the present study, we investigated the relationship of milk ARA with latitude, maternal vitamin D intake from fish and maternal vitamin D status. For this, we measured milk vitamin D concentrations, milk long-chain $n-3$ PUFA and maternal plasma $25(\mathrm{OH}) \mathrm{D}$ of lactating mothers living in countries at different latitudes and with diverse cultural backgrounds.

\section{Methods}

This cross-sectional study is part of the 'ZOOG' ('Zonder Ontsteking Oud en Gezond' translated: 'Without Inflammation Old and Healthy') project. The aim is to study relationships between maternal nutrient status and milk composition in various geographical regions with different cultural backgrounds with the ultimate aim to optimise human milk and formula compositions.

\section{Subjects, sample collection, storage and analysis}

Lactating mothers living in the Netherlands (latitude: $53^{\circ} \mathrm{N}$ ), Curaçao $\left(12^{\circ} \mathrm{N}\right)$, Vietnam (varying from $10-21^{\circ} \mathrm{N}$ ), Malaysia $\left(3^{\circ} \mathrm{N}\right)$ and Tanzania $\left(2^{\circ} \mathrm{S}\right)$ were invited to participate in the study. Inclusion criteria were that the women were apparently healthy and well nourished and gave birth to an apparently healthy term infant. Another inclusion criterion was that there were no pregnancy complications. 'Health and well nourishment' were self-proclaimed and by visual observation. The inhabitants of The Netherlands and Curaçao consumed typically Western diets, consisting of high carbohydrate and meat intakes, and low vegetable, fruit and fish intakes. One of the participants in Curaçao and all Dutch mothers took supplements that provided $10 \mu \mathrm{g}$ vitamin $\mathrm{D} / \mathrm{d}$, among other vitamins and minerals, during pregnancy and lactation. Most women from the Netherlands and Curaçao had a high socio-economic status. The Halong Bay province is located next to the Gulf of Tonkin, where seafood is widely consumed. Phu Tho is a rural province in northern Vietnam. It is among the poorest areas, where tea cultivation is one of the main agricultural activities. The diet is predominantly composed of rice. Tien Giang is a province in southern Vietnam located in the Mekong Delta. Agricultural and freshwater aquatic products are widely available. Ho Chi Minh City and Hanoi are the largest cities in the south and north of Vietnam, respectively. Most Vietnamese women had a low to average socio-economic status. Especially the women in Phu Tho and Tien Giang had a low socio-economic status. The Malaysian mothers consumed typical Malaysian diets, composed of rice, some fish and meats and vegetables. Most of them completed post-secondary school or college. In Tanzania, we included women from two different tribes: the Maasai and the people in Ukerewe. The Maasai have a semi-nomadic lifestyle. Most women had a low socio-economic status. The current diet of the Maasai consists mainly of beans, ugali (maize porridge), rice and chapatti (maize wheat pancakes) complemented with curdled milk and meat ${ }^{(22,23)}$. The people in Ukerewe (island in Lake Victoria) have very high intakes of freshwater fish ( $>7$ times/ week). Besides fish, their diets consist of some typically African staple foods such as ugali, muhogo (cassava root), beans and plantain (baked banana) ${ }^{(23)}$.

Earlier studies by Luxwolda et al. ${ }^{(24)}$ in Tanzania, Africa, showed that lactating women in Sengerema ( $n$ 28-30), Same ( $n$ 23-30) and Maasai ( $n$ 6) had mean plasma 25(OH)D levels between 80.1 (sD 27.5) and 99.3 (sD 20.9) nmol/1. Ho-Pham et $a l^{(25)}$ and Nguyen et $a l .{ }^{(26)}$ showed that Vietnamese women living in the South had a higher mean serum 25(OH)D level of 75.3 (sD 14.8) nmol/1 compared with 58.0 (sD 18.5) nmol/1 for women living in the Northern parts of Vietnam. Using the data of Luxwolda, Ho-Pham and Nguyen, we performed a power analysis and estimated that six to thirty women should be sufficient to provide insight whether women living in regions with adequate vitamin $\mathrm{D}$ status have adequate amounts of vitamin $\mathrm{D}$ in their milk. Differences in plasma 25(OH)D between two groups of eighteen subjects with mean plasma $25(\mathrm{OH}) \mathrm{D}$ concentrations of 99 and $80 \mathrm{nmol} / \mathrm{l}$, respectively, and between two groups of eleven subjects with mean serum 25(OH)D concentrations of 75 and $58 \mathrm{nmol} / \mathrm{l}$, respectively, can be detected with $80 \%$ power at $P<0 \cdot 05$.

Samples were collected in the Netherlands, Curaçao, Halong Bay, Phu Tho, Tien Giang, Ho Chi Minh City and Hanoi (all in Vietnam), Kuala Lumpur in Malaysia and in Tanzania from Maasai mothers living in Ruvu and mothers in Ukerewe (Lake Victoria) ${ }^{(23)}$. The studies in Curaçao, Vietnam, Malaysia and Tanzania were approved by the Ethics Committee of the St. Elisabeth Hospital in Willemstad, Curaçao; the Ethics Committee of The Family Food and Nutrition Institute in Hanoi, Vietnam; the International Medical University (IMU) Joint Committee of the Research and Ethics Committee in Kuala Lumpur, Malaysia; and the National Institute for Medical Research in Dar-es-Salaam, Tanzania (NIMR/HQ/R.8a/Vol.IX/ 8000), respectively. Women in the Netherlands merely provided us with a milk sample, which waves the need of official medical ethical clearance for its non-invasive nature. All women gave informed and/or written consent. The study was in agreement with the Helsinki declaration of 1975 as revised in 2013.

The mothers in the Netherlands, Curaçao and Vietnam were instructed to save a $25 \mathrm{ml}$ of milk sample that was taken from a 
completely emptied breast around noon. A quantity of $25 \mathrm{ml}$ milk samples in Malaysia were collected in the morning as far as possible. Tanzanian mothers collected a midstream sample at an undefined time during the day. Non-fasting venous EDTA-anticoagulated blood samples were taken from the women in Curaçao, Vietnam and in Tanzania-Ukerewe on the day of breast milk collection. Plasma was isolated by centrifugation at $2500 \boldsymbol{g}$ for $10 \mathrm{~min}$. We also had the opportunity to investigate six lactating mother-infants pairs living in TanzaniaUkerewe (ethics clearance: National Institute for Medical Research in Dar-es-Salaam, Tanzania (NIMR/HQ/R.8a/Vol.IX/ 8000)). For this we collected milk and blood of the mothers and infants at 4-22 postpartum (PP) weeks. All samples were collected in tubes and immediately frozen and stored at $-20^{\circ} \mathrm{C}$ (the Netherlands, Curaçao, Malaysia and Tanzania) and $-80^{\circ} \mathrm{C}$ (Vietnam). All samples were transported to the University Medical Center Groningen (the Netherlands) on dry ice. They were stored at $-20^{\circ} \mathrm{C}$ until analysis.

Before analysis, the breast milk samples were thawed at $37^{\circ} \mathrm{C}$. A $500-\mu$ aliquot was used for analysis of the vitamin D profile. Saponification and liquid-liquid extraction were performed essentially as described by Corso et al. ${ }^{(27)}$. Analysis took place by liquid-chromatography tandem MS (LC-MS/MS) after derivatisation with 4-[2-(3,4-dihydro-6,7-dimethoxy-4-methyl-3-oxo-2-quinoxalinyl)ethyl]-3H-1,2,4-triazole-3,5(4H)-dione (DMEQ-TAD), as described by Kamao et al. ${ }^{(28)}$. The inter-assay and intra-assay CV at $1.7-34.8 \mathrm{nmol} / 1$ were $<15$ and 10 , respectively, for all four analytes. The quantification limit was $0 \cdot 1 \mathrm{nmol} / 1$ for vitamin $\mathrm{D}_{3}$ and $\mathrm{D}_{2}$ and $0.2 \mathrm{nmol} / 1$ for $25(\mathrm{OH}) \mathrm{D}_{3}$ and $25(\mathrm{OH}) \mathrm{D}_{2}$. Vitamin $\mathrm{D}_{3}$ and vitamin $\mathrm{D}_{2}$ were summed to vitamin $\mathrm{D}$, whereas $25(\mathrm{OH}) \mathrm{D}_{3}$ and its $\mathrm{D}_{2}$ analogue were combined to $25(\mathrm{OH}) \mathrm{D}$. For milk ARA calculation, 1 IU/L was equal to $25 \mathrm{pg} / \mathrm{ml}$ vitamin $\mathrm{D}$ and $5 \mathrm{pg} / \mathrm{ml} 25(\mathrm{OH}) \mathrm{D}$.

Plasma $25(\mathrm{OH}) \mathrm{D}_{3}$ and $25(\mathrm{OH}) \mathrm{D}_{2}$ (together referred to as $25(\mathrm{OH}) \mathrm{D})$ were measured with isotope dilution-online solidphase extraction LC-MS/MS, as described by Luxwolda et al. ${ }^{(24)}$. The milk fatty acid composition was measured by GC with flame ionisation detection ${ }^{(29)}$. Milk EPA and DHA acids were expressed in $\mathrm{g} / 100 \mathrm{~g}$ fatty acids $(\mathrm{g} \%)$. The inter-assay and intraassay variations for EPA $(0.06 \mathrm{~g} \%)$ and DHA (0.45 g\%) were $<15 \%{ }^{(30)}$. We used the milk EPA + DHA content as a proxy for fish intake.

\section{Data analysis and statistics}

Cut-off values for vitamin D of 25,50 and $80 \mathrm{nmol} / \mathrm{l}^{(11,31,32)}$ were applied to report vitamin D deficiency $(<25 \mathrm{nmol} / \mathrm{l})$, vitamin D insufficiency $(25-49.9 \mathrm{nmol} / \mathrm{l})$, hypovitaminosis D (50-79.9 nmol/1), vitamin D sufficiency $(80-249.9 \mathrm{nmol} / \mathrm{l})$ and vitamin D toxicity $(\geq 250 \mathrm{nmol} / \mathrm{l})$.

The IBM PASW Statistics 22 software was used. As not all data were Gaussian distributed, we reported medians and ranges. Results below the limit of quantification were used, because this did not alter our conclusions. Relationships were analysed by use of bivariate correlation analysis and using the Spearman's $\rho$ test for calculating $r$. A linear regression model was made, using backwards regression, to assess determinants of milk ARA. The milk ARA was log-transformed as these data were not normally distributed. As covariates, we used maternal plasma
25(OH)D, latitude, milk DHA + EPA, maternal age, lactation duration and BMI. A $P$ value $<0.05$ was considered significant.

\section{Results \\ Study population, milk antirachitic activity, plasma 25-hydroxyvitamin D and milk EPA + DHA}

Table 1 shows the characteristics of the investigated mothers and their infants, together with the milk ARA, maternal plasma 25(OH)D (available for Curaçao ( $n$ 9), Vietnam $(n$ 100) and Tanzania-Ukerewe $(n$ 20)), and the milk EPA+DHA contents. None of the 181 lactating mothers, that is nine in the Netherlands, ten in Curaçao, 101 in Vietnam, twenty in Malaysia and forty-one in Tanzania, reached the vitamin D IOM AI in their milk. Milk ARA was mainly composed of vitamin $\mathrm{D}_{3}$ and $25(\mathrm{OH}) \mathrm{D}_{3}$. Their $\mathrm{D}_{2}$ analogues were generally below the detection limit. The median milk ARA of the total population was $45 \mathrm{IU} / 1$ (range: 1-247 IU/1).

Fig. 1 shows, for each of the subpopulations, the milk ARA as box plots (medians, ranges, 25th-75th percentiles and 5th-95th percentiles). The women in The Netherlands, Malaysia, Vietnam-Hanoi and Vietnam-Phu Tho exhibited the lowest milk ARA, whereas those in Tanzania-Ukerewe, Tanzania-Maasai and Vietnam-Tien Giang showed the highest. It appeared that low latitude is no guarantee for adequate milk ARA. We found median plasma 25(OH)D concentrations of 71 (range 27-132) nmol/l in the mothers from Curaçao, Vietnam and Tanzania-Ukerewe.

We found that none of these women had vitamin $\mathrm{D}$ deficiency $(25(\mathrm{OH}) \mathrm{D}<25 \mathrm{nmol} / \mathrm{l}), 19.4 \%$ had vitamin D insufficiency $(25-49.9 \mathrm{nmol} / \mathrm{l}), \quad 47.3 \%$ had hypovitaminosis $\mathrm{D}$ $(50-79 \cdot 9 \mathrm{nmol} / \mathrm{l})$ and $33.3 \%$ had sufficient vitamin D status (80-249.9 nmol/1). The milk EPA + DHA content ranged from $0 \cdot 1$ to $3 \cdot 1 \mathrm{~g} \%$ with a median of $0.4 \mathrm{~g} \%$. Lowest medians were found in the Netherlands, Curaçao and Vietnam-Phu Tho and highest in Tanzania-Ukerewe (located at Lake Victoria).

\section{Determinants of milk antirachitic activity}

Fig. 2 shows the relationships between maternal plasma 25(OH)D and milk ARA (Fig. 2(a); $r 0.48, P<0 \cdot 01$ ), maternal plasma 25(OH)D and milk vitamin D (Fig. 2(b); $r 0.43, P<0.01$ ) and maternal plasma 25(OH)D and milk 25(OH)D (Fig. 2(c); $r 0.38, P<0.01)$, for mothers in Curaçao, Vietnam and Tanzania-Ukerewe. Fig. 3 shows the relationships between milk EPA + DHA and milk ARA (Fig. 3(a); $r 0 \cdot 41, P<0 \cdot 01$ ), milk $\mathrm{EPA}+\mathrm{DHA}$ and milk vitamin D (Fig. 3(b); $r 0.51, P<0.01$ ) and milk EPA+DHA and milk 25(OH)D (Fig. 3(c); $r 0 \cdot 15, P=0 \cdot 06$ ), for mothers in the Netherlands, Curaçao, Vietnam, Malaysia and Tanzania-Ukerewe.

Using backwards regression in a linear regression model with integrated data from Curaçao, Vietnam and Tanzania-Ukerewe, we found that milk ARA was related to maternal plasma $25(\mathrm{OH}) \mathrm{D}$ $(\beta 0.40 ; P<0 \cdot 01)$, latitude $(\beta-0 \cdot 21 ; P<0 \cdot 01)$ and milk EPA + DHA ( $\beta 0.20 ; P<0.05)$. The model had an adjusted $R^{2}$ of 0.34 . In the linear regression model with backwards regression, we found that maternal age, lactation duration and BMI were unrelated with milk ARA. 
Table 1. Mothers and infants

(Medians and ranges; numbers and percentages)

\begin{tabular}{|c|c|c|c|c|c|c|c|c|c|c|c|c|c|c|c|c|c|c|c|c|c|}
\hline \multirow[b]{2}{*}{ Characteristics } & \multirow[b]{2}{*}{ Dimension } & \multicolumn{2}{|c|}{$\begin{array}{l}\text { The Netherlands } \\
\qquad(n 9)\end{array}$} & \multicolumn{2}{|c|}{$\begin{array}{c}\text { Curaçao } \\
(n 10)\end{array}$} & \multicolumn{2}{|c|}{$\begin{array}{l}\text { Vietnam-Halong } \\
\text { Bay }(n \text { 20) }\end{array}$} & \multicolumn{2}{|c|}{$\begin{array}{l}\text { Vietnam-Phu } \\
\text { Tho ( } n \text { 22) }\end{array}$} & \multicolumn{2}{|c|}{$\begin{array}{l}\text { Vietnam-Tien } \\
\text { Giang }(n \text { 20) }\end{array}$} & \multicolumn{2}{|c|}{$\begin{array}{l}\text { Vietnam-Ho Chi } \\
\text { Minh City }(n \text { 18) }\end{array}$} & \multicolumn{2}{|c|}{$\begin{array}{l}\text { Vietnam-Hanoi } \\
(n 21)\end{array}$} & \multicolumn{2}{|c|}{$\begin{array}{l}\text { Malaysia-Kuala } \\
\text { Lumpur }(n \text { 20) }\end{array}$} & \multicolumn{2}{|c|}{$\begin{array}{c}\text { Tanzania-Ukerewe } \\
(n 21)\end{array}$} & \multicolumn{2}{|c|}{$\begin{array}{c}\text { Tanzania-Maasai } \\
(n \text { 20) }\end{array}$} \\
\hline & & Median & Range & Median & Range & Median & Range & Median & Range & Median & Range & Median & Range & Median & Range & Median & Range & Median & Range & Median & Range \\
\hline ge & Years & 30 & $28-33$ & 31 & $21-40$ & 28 & $19-37$ & 26 & $21-34$ & 31 & $21-39$ & 28 & $22-38$ & 28 & $19-42$ & 31 & $22-40$ & 25 & $16-36$ & 25 & $17-37$ \\
\hline 4 & & 174 & 16 & 1 & $147-$ & 156 & 143-163 & 153 & $144-165$ & 152 & 145 & 155 & 146 & 153 & $146-158$ & 155 & 63 & 156 & 147 & 159 & $151-176$ \\
\hline Weight & $\mathrm{k}$ & 62 & $54-76$ & 67 & $60-76$ & 51 & $43-71$ & 46 & $40-62$ & 51 & $41-70$ & 55 & $46-68$ & 52 & $44-59$ & 61 & $43-90$ & 57 & $46-$ & 53 & $44-89$ \\
\hline BMI & $\mathrm{kg} / \mathrm{m}^{2}$ & 21 & $18-28$ & 27 & 20-32 & 21 & $18-27$ & 20 & $17-23$ & 22 & $18-33$ & 24 & $19-28$ & 22 & $20-28$ & 26 & $18-35$ & 22 & $18-28$ & 21 & $17-34$ \\
\hline Gravida & $\mathrm{n}$ & 1 & $1-2$ & n.k. & & 2 & $1-3$ & 2 & $2-4$ & 2 & $2-4$ & 2 & $2-4$ & 2 & $2-3$ & 3 & $1-6$ & n.k. & & n.k. & \\
\hline Para & $\mathrm{n}$ & 0 & $0-2$ & n.k. & & 2 & $1-3$ & 2 & & 2 & 2 & 2 & 2 & 2 & 2 & 3 & $1-6$ & 3 & $1-6$ & 2 & $1-11$ \\
\hline $\begin{array}{l}\text { Infant birth weight } \\
\text { Infant sex }\end{array}$ & $\stackrel{g}{\%}$ males & 3728 & $\begin{array}{l}2995-4060 \\
44\end{array}$ & 3120 & $\begin{array}{l}2440-3650 \\
60\end{array}$ & 3200 & $\begin{array}{l}2500-3900 \\
65\end{array}$ & 3050 & $\begin{array}{l}2500-3700 \\
50\end{array}$ & 3100 & $\begin{array}{l}2700-4500 \\
65\end{array}$ & 3200 & $\begin{array}{l}2600-3900 \\
44\end{array}$ & 3300 & $\begin{array}{l}2700-4400 \\
57\end{array}$ & 3298 & $\begin{array}{l}2340-3750 \\
30\end{array}$ & 3200 & $\begin{array}{l}2200-3600 \\
43\end{array}$ & $\begin{array}{l}\text { n.k. } \\
\text { n.k. }\end{array}$ & \\
\hline Infant weight 'at sampling' & $\mathrm{kg}$ & 4.9 & $3 \cdot 5-5 \cdot 8^{\star}$ & 4.6 & $3 \cdot 8-5 \cdot 8$ & 4.9 & $3.8-5.8$ & 4.6 & $3.5-5.7$ & 4.8 & $3 \cdot 9-5 \cdot 6$ & 5 & $3 \cdot 6-6$ & 4.7 & $4-5.8$ & n.k. & & 5.5 & $3.5-8.1$ & n.k. & \\
\hline $\begin{array}{l}\text { Lactation duration 'at the time of } \\
\text { sampling' } \\
\text { Vitamin D supplements } \\
(10 \text { ug/d) to infants }\end{array}$ & weeks & 6 & $4-10$ & 6 & $4-11$ & 6 & $4-6$ & 5.5 & $4-6$ & 5 & $4-6$ & 5 & $4-6$ & 5 & $4-6$ & 6 & $4-11$ & 9 & $4-25$ & 12 & $4-17$ \\
\hline$n$ & & & 9 & & 0 & & 1 & & 1 & & 1 & & 4 & & 1 & & 0 & & 0 & & 0 \\
\hline$\%$ & & & 100 & & 0 & & 5 & & 5 & & 5 & & 22 & & 5 & & 0 & & 0 & & 0 \\
\hline Milk & & 0.25 & 0.02 & 0.80 & & 0.56 & & 0.21 & & 1.75 & & 0.88 & & 0.21 & & 0.15 & & 2.66 & 0.5 & 1.93 & 0.2 \\
\hline & & 0.5 & & 0.23 & & 2 & & 0.24 & & 0.43 & & 0.43 & & 0.38 & & 0.11 & & 0.32 & & 0.72 & $0.42-1.13$ \\
\hline & & 1 & & 3. & & 5 & & 2 & & 63 & & 49 & & 37 & & 14 & & 77 & & 88 & $43-189$ \\
\hline H) D AF & & 9 & & 7 & & 7 & & 8 & & 50 & & 73 & & 89 & & 78 & 0 & 31 & & 65 & $21-97$ \\
\hline Plas & $\mathrm{nmol} / \mathrm{l}$ & n.c. & & $62^{*}$ & $35-122$ & 75 & 32 & 66 & $27-$ & 72 & 49 & 62 & 42 & $60^{*}$ & 37 & n.c. & $\mathrm{n}$. & $76^{*}$ & 53 & n.c. & n.c. \\
\hline & $\mathrm{g}$ & 0.1 & & 0 & & 0.2 & & 0 & & 0.1 & & 0.1 & & 0 & 0 & 0.1 & 0 & 0.3 & $0.2-0.5$ & $\mathrm{~N} / \mathrm{A}$ & \\
\hline & $g \%$ & $\begin{array}{l}0.2 \\
0.3\end{array}$ & $\begin{array}{l}0.1-0.3 \\
0.2-0.4\end{array}$ & $\begin{array}{l}0.2 \\
0.3\end{array}$ & $\begin{array}{l}0.1-0.3 \\
0.1-0.4\end{array}$ & $\begin{array}{l}0.5 \\
0.8\end{array}$ & $0.2-1.9$ & $\begin{array}{l}0.3 \\
0.3\end{array}$ & & $\begin{array}{l}0.4 \\
0.5\end{array}$ & & $\begin{array}{l}0.4 \\
0.5\end{array}$ & & 0.3 & 0.2 & 0.4 & 0.3 & 1.1 & $0.4-1 \cdot 4$ & $\mathrm{~N} / \mathrm{A}$ & \\
\hline Milk EPA+DHA & $\mathrm{g} \%$ & & $0.2-0.4$ & 0.3 & $0.1-0.4$ & 0.8 & $0.2-1.9$ & 0.3 & $0.2-0.7$ & 0.5 & $0.2-1.5$ & 0.5 & $0.2-3 \cdot 1$ & 0.4 & $0.2-0.6$ & 0.5 & $0 \cdot 3-1 \cdot 1$ & 1.4 & $0.5-1.9$ & $N / A$ & \\
\hline
\end{tabular}

n.k., not known; ARA, antirachitic activity; 25(OH)D, 25-hydroxyvitamin D; n.c., not collected; N/A, not analysed.

Not complete: 1 missing 


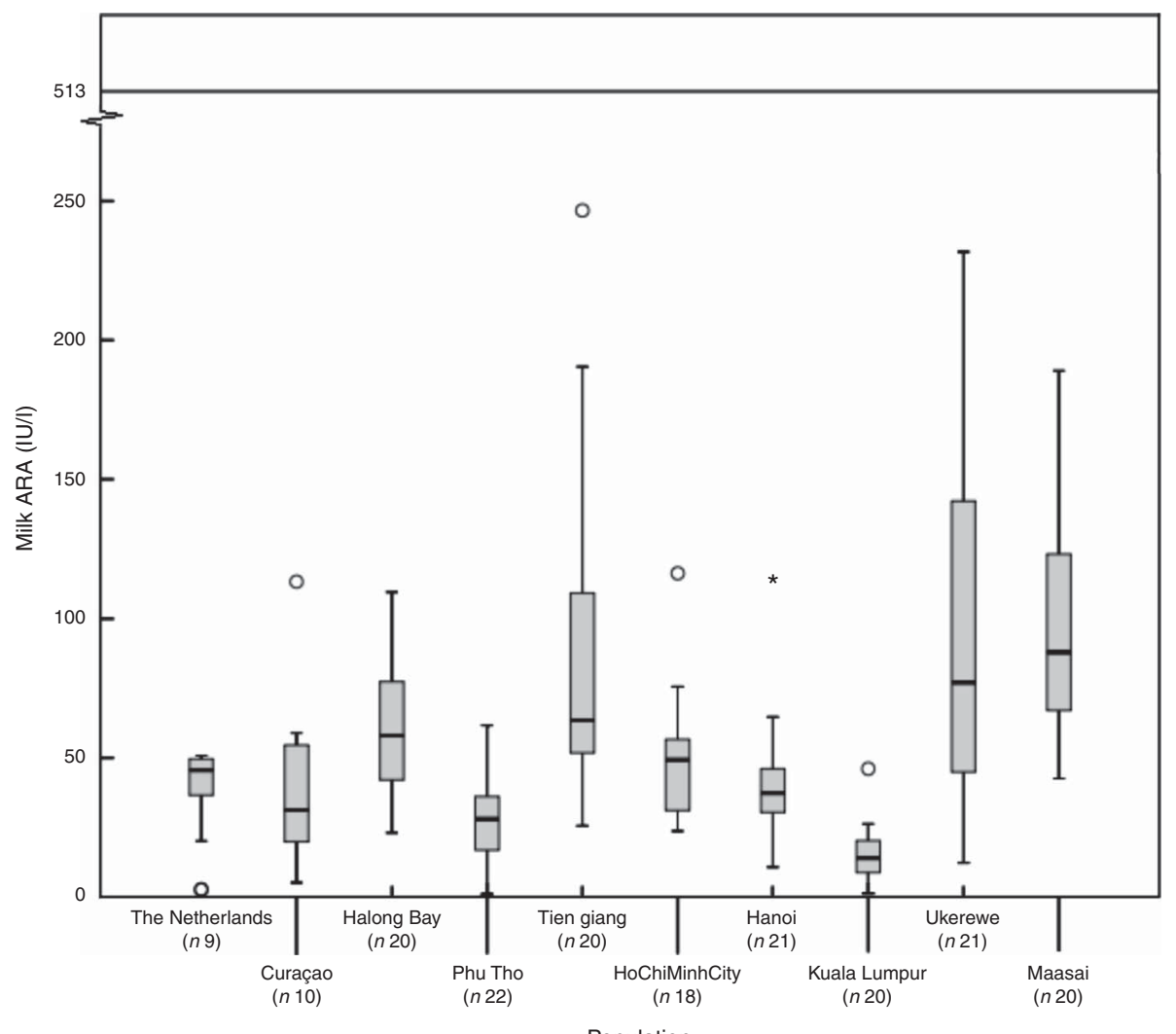

Fig. 1. Milk antirachitic activity (ARA) of the investigated populations. Adequate intake of $10 \mu \mathrm{g}$ vitamin D/d (milk ARA of 513 IU/l) for $0-6-$ month-old infants, as set by the Institute of Medicine. * Outlier.
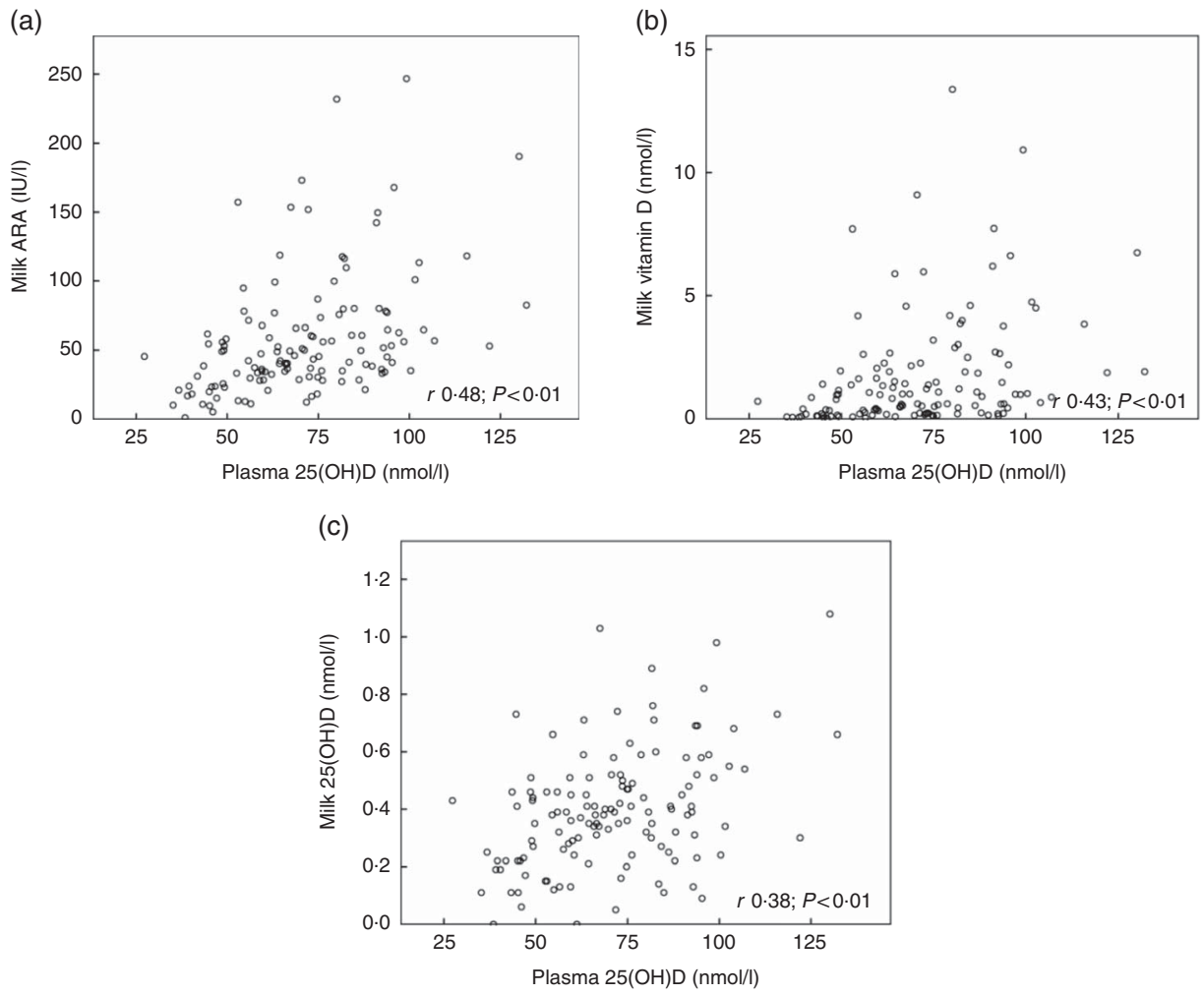

Fig. 2. Relationships between maternal plasma 25 -hydroxyvitamin $D(25(\mathrm{OH}) \mathrm{D})$ and milk antirachitic activity $(\mathrm{ARA})(\mathrm{a})$, maternal plasma $25(\mathrm{OH}) \mathrm{D}$ and milk vitamin $\mathrm{D}$ (b) and maternal plasma 25(OH)D and milk 25(OH)D (c) for 129 healthy lactating mothers in Curaçao, Vietnam and Tanzania-Ukerewe. 
(a)

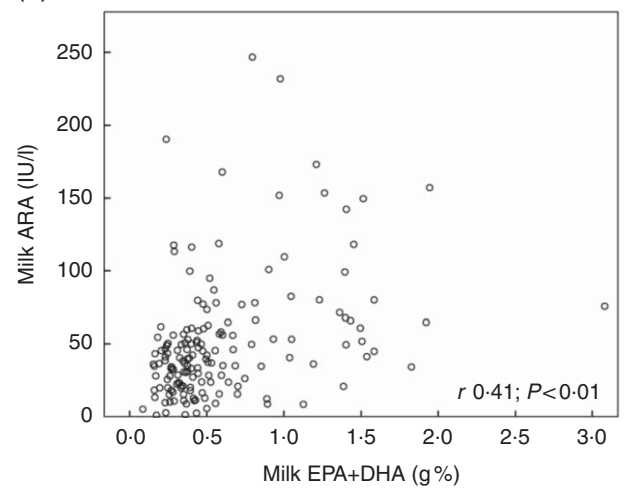

(b)

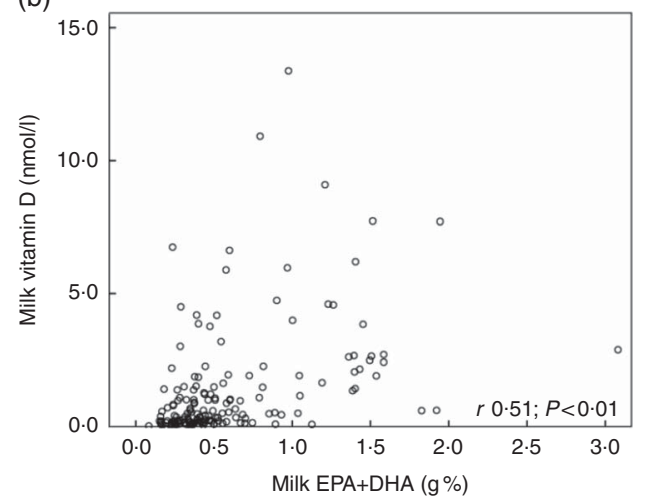

(c)

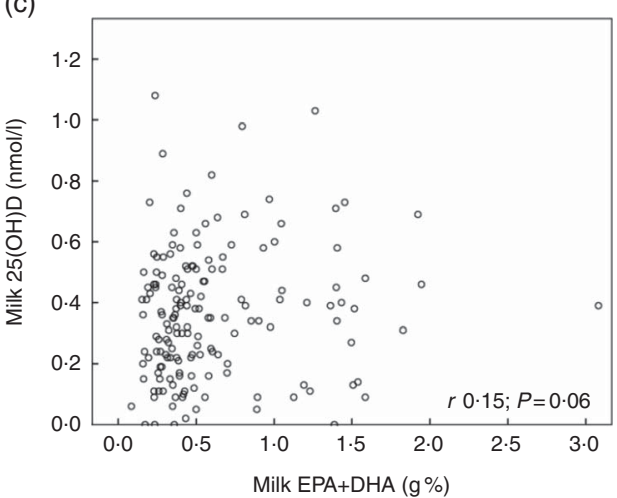

Fig. 3. Relationships between milk EPA + DHA and milk antirachitic activity (ARA) (a), milk EPA +DHA and milk vitamin D (b) and milk EPA + DHA milk and 25-hydroxyvitamin D (25(OH)D) (c) for 161 healthy lactating mothers in the Netherlands, Curaçao, Vietnam, Malaysia and Tanzania-Ukerewe. Milk DHA + EPA were used as a proxy of fish intake.

\section{Six lactating mother-infant pairs living in Tanzania-Ukerewe}

The online Supplementary Fig. S1 shows the individual motherchild relationship for plasma $25(\mathrm{OH}) \mathrm{D}$ at 4-22 PP weeks. Maternal plasma 25(OH)D ranged from 53 to $93 \mathrm{nmol} / \mathrm{l}$; their exclusively breast-fed infants exhibited $52-85 \mathrm{nmol} / \mathrm{l}$, whereas the milk ARA ranged from 34 to 173 IU/1.

\section{Discussion}

In this study, we determined the milk ARA of mothers living in five different countries (the Netherlands, Curaçao, Vietnam, Malaysia and Tanzania), located at latitudes ranging from $2^{\circ} \mathrm{S}$ to $53^{\circ} \mathrm{N}$. The median milk ARA concentration of the entire study population was $45 \mathrm{IU} / 1$ (range: $1-247 \mathrm{IU} / 1 ; n$ 181; Table 1). None of the milk samples reached the IOM AI of 513 IU/1 (Fig. 1). The median maternal $25(\mathrm{OH}) \mathrm{D}$ of the women in Curaçao, Vietnam and Tanzania-Ukerewe was 71 (range: 27-132) nmol/l. Maternal plasma 25(OH)D, latitude and milk EPA + DHA were determinants of milk ARA (Fig. 2 and 3), whereas maternal age, lactation duration and BMI were unrelated.

The finding of maternal plasma 25(OH)D, latitude (a proxy for UV-B exposure) and milk EPA + DHA (proxy for fish intake) as determinants of milk ARA is in agreement with the influences of maternal sunlight exposure, maternal vitamin D intake and possibly maternal stores ${ }^{(8,19)}$. The milk ARA outputs were not even close to the AI of the IOM for 0-6-month-old infants. The low milk ARA, especially in mothers with sufficient vitamin D status, or those with lifetime exposure to all-year-round abundant sunshine, are puzzling from an evolutionary point view. This finding raises the question of milk vitamin $\mathrm{D}$ adequacy for infants who in the past were born at latitudes with insufficient vitamin D UV-B synthesising capacity, notably in winter. The loss of skin pigmentation following the Out-of-Africa diaspora, occurring independently in Europeans and Asians, is widely acknowledged to reflect adaptation to the lower UV-B exposure that comes along with higher latitudes ${ }^{(33)}$. That sunlight exposure seems unable to raise milk ARA to the IOM AI was previously suggested by the study of Greer et al. ${ }^{(34)}$. They demonstrated a maximal milk vitamin $\mathrm{D}_{3}$ increase of only $60 \mathrm{IU} / 1$, following $2 \mathrm{~d}$ total body UV-B exposure of healthy lactating white women to a 1.5 minimal erythemal dose. This level of exposure approximated $30 \mathrm{~min}$ sunshine at mid-day on a clear summer day at temperate latitudes. The inability of lactating mothers to reach the IOM AI of $10 \mu \mathrm{g}$ vitamin D/d by natural means became also illustrated by the very high supplemental dose needed to reach this level. Daily supplementation of $50 \mu \mathrm{g}$ (2000 IU) from 27 gestational weeks resulted in a milk ARA of only $64 \mathrm{IU} / 1$ at 2 weeks PP and $56 \mathrm{IU} / 1$ at 2 months $\mathrm{PP}^{(19)}$. Wagner et al. ${ }^{(35)}$ showed that supplementing lactating mothers with $160 \mu \mathrm{g}$ (6400 IU) vitamin D/d from 1 month PP for 6 months caused a gradual increase of the milk vitamin D concentration to reach an ARA of $873 \mathrm{IU} / 1$ at the study end. This study was followed by a multi-year, two-site RCT demonstrating this approach to be both safe and effective for 
providing adequate vitamin $\mathrm{D}$ to the nursing infant ${ }^{(36)}$. Even though there are no apparent safety risks with an intake of $160 \mu \mathrm{g}$ vitamin $\mathrm{D} / \mathrm{d}$, this dosage is well above the current upper limit of $100 \mu \mathrm{g} / \mathrm{d}^{(37)}$ and corresponds with the daily consumption of about $1.7 \mathrm{~kg}$ average pelagic marine fish $^{(38)}$.

The inability of milk to reach the IOM vitamin D AI by natural means suggests that either the needed oral intake for 0-6month-old infants is much lower than the currently recognised $10 \mu \mathrm{g}$ AI or that breast-fed infants should rely on their vitamin D stores. The high plasma $25(\mathrm{OH}) \mathrm{D}$ concentrations in the six lactating mother-child pairs in Tanzania-Ukerewe suggest that a lifetime high maternal vitamin D status of the mother is capable of guaranteeing an adequate vitamin $\mathrm{D}$ status in her exclusively breast-fed child, despite her relatively low milk ARA. In view of the local culture and habits, other potential infant vitamin D sources, such as sun exposure, non-human milk dietary sources or supplements, are unlikely. Little is known on the sizes of vitamin D stores in humans and the factors determining their mobilisation. However, fasting of previously vitamin-D-loaded rats caused a slower 25(OH)D decline, compared with ad libitum-fed counterparts ${ }^{(39)}$. Didriksen et al. ${ }^{(40)}$ recently showed that vitamin $\mathrm{D}_{3}$ increased in abdominal subcutaneous fat tissue after supplementation with vitamin $\mathrm{D}_{3}$. It is well known that the body fat mass of nonpregnant subjects exhibits an inverse relation with plasma $25(\mathrm{OH}) \mathrm{D}^{(41)}$

Our previous study showed a higher $25(\mathrm{OH}) \mathrm{D}$ in pregnant women in Tanzania from the first trimester until delivery, when compared with non-pregnant counterparts ${ }^{(24)}$. After delivery, plasma $25(\mathrm{OH}) \mathrm{D}$ dropped steeply to reach non-pregnant values. Such changes were not observed in women living in Western countries ${ }^{(42-44)}$. We suggested that the observed course of $25(\mathrm{OH}) \mathrm{D}$ in traditionally living pregnant women in Tanzanian may reflect mobilisation of vitamin $\mathrm{D}$ from adipose tissue stores $^{(24)}$ and/or 25(OH)D from muscle ${ }^{(45)}$. Among the various organs, adipose tissue has been estimated to contain about $75 \%$ of total body vitamin D, whereas $25(\mathrm{OH}) \mathrm{D}$ is more evenly distributed with high contents in adipose tissue, serum and muscle ${ }^{(46)}$. The driver of vitamin D mobilisation from fat might be the state of 'accelerated starvation and facilitated anabolism' that is operational throughout pregnancy to ensure sufficient fluxes of glucose, fatty acids and other nutrients for the benefit of the fetus ${ }^{(47)}$. Trapping of vitamin $\mathrm{D}$ in the maternal circulation may occur by oestrogen-induced augmentation of circulating vitamin $\mathrm{D}$ binding protein (DBP). Plasma DBP has short half-life of $2.5-3 \mathrm{~d}$ and falls immediately after delivery ${ }^{(48)}$. Vitamin D may easily traverse the placenta because of its relatively low affinity for DBP, whereas the more tightly bound $25(\mathrm{OH}) \mathrm{D}$ may traverse mostly via the cubilinmegalin system ${ }^{(49)}$. The TAG in the rapidly growing, mostly subcutaneous, fetal adipose compartment, are about $80 \%$ de novo synthesised from polar precursors, notably glucose and lactate. This rapidly growing, vitamin-D-naive, fat compartment, harbouring $50 \%$ TAG at the pregnancy end ${ }^{(50)}$, might exert high attraction for the (hydrophobic) vitamin D from maternal origin. The concerted action of oestrogens, DBP and the lower insulin sensitivity in pregnancy may jointly facilitate an almost one-way transplacental transfer of hydrophobic nutrients, and thereby contribute to the equilibration of vitamin D between maternal and fetal stores. Following this line of reasoning, it would be the maternal adipose tissue vitamin D content, that is in particular the maternal lifetime sun exposure and vitamin D intake, that determines the magnitude of the infant's vitamin D store at birth. Taken together, we propose that the vitamin D status of exclusively breast-fed infants might notably be dependent on maternal stores and the ability to mobilise these stores during pregnancy and lactation. Like the infant status of $\mathrm{Fe}^{(51)}$ and vitamin $\mathrm{B}_{12}$ (E Stoutjesdijk, unpublished results), the vitamin D status of exclusively breast-fed infants might be strongly dependent on the size of their stores acquired during fetal life. Finally, although postnatal adequate infant vitamin D status can be reached by supplements or human milk ${ }^{(35)}$, it might be better to ensure adequate vitamin D status during both fetal and early postnatal life. This notion shifts the attention of adequate vitamin D status from pregnancy and lactation to preconception.

Limitations of this study are the inter-individual differences in the duration of lactation (4-25 weeks), the different milk collection methods, the incomplete collection of blood samples and differences in season. We had no information on the plasma $25(\mathrm{OH}) \mathrm{D}$ levels of the women living in the Netherlands, Malaysia and Maasai. In our linear regression model, we did not identify lactation duration as a confounder. Moreover, the IOM AI is defined for the entire period from birth to 6 postnatal months. Ala-Houhala et $a l^{(9)}$ and við Streym et al. ${ }^{(10)}$ found differences in milk vitamin D and 25(OH)D between fore- and hind milks. These differences in median milk ARA did not exceed $50 \mathrm{IU} / \mathrm{l}$, suggesting that sampling imperfections did not affect our conclusions. Regarding differences in season, as most of our studied population live close to the equator, other factors such as short and longer rainy periods, air pollution, clothing and sun-avoiding behaviour could be greater sources of interindividual variation. Other limitations are that we did not collect dietary data. An analytical limitation is that many of the milk vitamin $\mathrm{D}$ and $25(\mathrm{OH}) \mathrm{D}$ concentrations were close to the detection limit of our method. This is, however, a problem with all published ARA data until now and does not take away the message that milk ARA does not reach the $10 \mu \mathrm{g}$ vitamin D AI of the IOM. Finally, the number of studied mothers and motherinfant pairs was low.

In conclusion, milk ARA of mothers, including mothers with lifetime abundant sunlight exposure, is not even close to the $10 \mu \mathrm{g}$ vitamin D AI for 0-6-month-old infants. Maternal plasma $25(\mathrm{OH}) \mathrm{D}$, latitude and milk EPA + DHA are related with milk ARA. The increase of plasma $25(\mathrm{OH}) \mathrm{D}$ in traditionally living pregnant women, the increase of DBP during pregnancy and the intra-uterine growth of a sizeable vitamin-D-naive fetal adipose compartment suggest that, during pregnancy, maternal vitamin D may become transferred across the placenta to subsequently equilibrate with fetal stores. Storage of $25(\mathrm{OH}) \mathrm{D}$ in muscle and its mobilisation by physical activity ${ }^{(45)}$ is another, yet poorly understood, option. Our data may point at the importance of adequate fetal vitamin D stores and shifts the attention from adequate vitamin D status during pregnancy and lactation to adequacy starting before conception. Information on maternal and fetal adipose tissue vitamin D contents, 
$25(\mathrm{OH}) \mathrm{D}$ in muscle and the factors governing their mobilisation are needed.

\section{Acknowledgements}

The authors thank the UMCG Laboratory for Special Chemistry for analyses, Martine Luxwolda, Remko Kuipers, Jan van der Molen and master students Willem Abma, Valesca Wangsawirana and Wietske Hemminga for their participation in this study.

This work was supported by Ministry of Economic Affairs, the Provinces of Groningen and Drenthe.

Designed research: all authors; conducted research: E. S., N. V. N. and G. L. K.; statistical analysis: E. S.; wrote the paper: E. S., D. A. J. D.-B. and F. A. J. M.; primary responsibility for final content: F. A. J. M. All Authors have read and approved the final manuscript.

None of the authors has any conflicts of interest to declare.

\section{Supplementary material}

For supplementary material/s referred to in this article, please visit https://doi.org/10.1017/S000711451700277X

\section{References}

1. Shaw NJ (2016) Prevention and treatment of nutritional rickets. I Steroid Biochem Mol Biol 164, 145-147.

2. Javaid MK, Crozier SR, Harvey NC, et al. (2006) Maternal vitamin D status during pregnancy and childhood bone mass at age 9 years: a longitudinal study. Lancet 367, 36-43.

3. Holick MF (2004) Sunlight and vitamin D for bone health and prevention of autoimmune diseases, cancers, and cardiovascular disease. Am J Clin Nutr 80, 6 Suppl., 1678S-1688S.

4. Dinlen N, Zenciroglu A, Beken S, et al. (2016) Association of vitamin D deficiency with acute lower respiratory tract infections in newborns. J Matern Fetal Neonatal Med 29, 928-932.

5. Ali SR \& McDevitt H (2015) Question 1: does vitamin D supplementation prevent acute lower respiratory tract infections in children? Arch Dis Child 100, 892-895.

6. Eyles DW, Burne TH \& McGrath JJ (2013) Vitamin D, effects on brain development, adult brain function and the links between low levels of vitamin $\mathrm{D}$ and neuropsychiatric disease. Front Neuroendocrinol 34, 47-64.

7. Dawodu A \& Akinbi H (2013) Vitamin D nutrition in pregnancy: current opinion. Int J Womens Health 5, 333-343.

8. Dawodu A \& Tsang RC (2012) Maternal vitamin D status: effect on milk vitamin D content and vitamin D status of breastfeeding infants. Adv Nutr 3, 353-361.

9. Ala-Houhala M, Koskinen T, Parviainen MT, et al. (1988) 25-Hydroxyvitamin D and vitamin D in human milk: effects of supplementation and season. Am J Clin Nutr 48, 1057-1060.

10. við Streym S, Hojskov CS, Moller UK, et al. (2016) Vitamin D content in human breast milk: a 9-mo follow-up study. Am J Clin Nutr 103, 107-114.

11. Institute of Medicine (US) Committee to Review Dietary Reference Intakes for Vitamin D and Calcium (2011) Vitamin D: dietary reference intakes for adequacy. In Dietary Reference Intakes for Calcium and Vitamin D, pp. 345-402 [AC Ross, CL Taylor, AL Yaktine, et al., editors]. Washington, DC: National Academies Press.
12. Neville MC, Keller R, Seacat J, et al. (1988) Studies in human lactation: milk volumes in lactating women during the onset of lactation and full lactation. Am J Clin Nutr 48, 1375-1386.

13. American Academy of Pediatrics \& Committee on Environmental Health (1999) Ultraviolet light: a hazard to children. Pediatrics 104, 328-333.

14. Wagner CL \& Greer FR American Academy of Pediatrics Section on Breastfeeding et al (2008) Prevention of rickets and vitamin D deficiency in infants, children, and adolescents. Pediatrics 122, 1142-1152.

15. Braegger C, Campoy C, Colomb V, et al. (2013) Vitamin D in the healthy European paediatric population. I Pediatr Gastroenterol Nutr 56, 692-701.

16. Rijksinstituut voor Volksgezondheid en Milieu (2011) Dutch National Food Consumption Survey 2007-2010: Diet of children and adults aged 7 to 69 years. http://www.rivm.nl/ Documenten_en_publicaties/Wetenschappelijk/Rapporten/2011/ oktober/Dutch_National_Food_Consumption_Survey_2007_ 2010_Diet_of_children_and_adults_aged_7_to_69_years (accessed March 2014).

17. Health Council of the Netherlands (2012) Evaluation of Dietary Reference Values for Vitamin D. The Hague: Health Council of the Netherlands, publication no. 2012/15E. https://www.gezond heidsraad.nl/en/publications/gezonde-voeding/evaluation-of-thedietary-reference-values-for-vitamin-d (accessed March 2016).

18. USDA food composition databases. Show nutrient list - vitamin D. https://ndb.nal.usda.gov/ndb/nutrients/report/nutrientsfrm?max= 25\&offset $=0$ \&totCount $=0$ \&nutrient $1=328$ \&nutrient $2=$ \&nutrient $3=$ \&subset $=0 \& f g=\&$ sort $=$ c\&measureby $=\mathrm{m}$, (accessed March 2015).

19. Wall CR, Stewart AW, Camargo CA Jr, et al. (2016) Vitamin D activity of breast milk in women randomly assigned to vitamin $\mathrm{D}_{3}$ supplementation during pregnancy. Am J Clin Nutr 103, 382-388.

20. Hollis BW \& Wagner CL (2004) Vitamin D requirements during lactation: high-dose maternal supplementation as therapy to prevent hypovitaminosis $\mathrm{D}$ for both the mother and the nursing infant. Am J Clin Nutr 80, 6 Suppl., 1752S-1758S.

21. Saadi HF, Dawodu A, Afandi B, et al. (2009) Effect of combined maternal and infant vitamin $\mathrm{D}$ supplementation on vitamin D status of exclusively breastfed infants. Matern Child Nutr 5, 25-32.

22. Oiye S, Olesimel J, Oniango R, et al. (2009) Chapter 11: The Maasai food system and food and nutrition security. In Indigenous Peoples' Food Systems: the Many Dimensions of Culture, Diversity and Environment for Nutrition and Health, pp. 231 [HV Kuhnlein, B Erasmus and D Spigelski, editors]. Rome: Food and Agriculture Organization of the United Nations Centre for Indigenous Peoples' Nutrition and Environment.

23. Luxwolda MF, Kuipers RS, Koops JH, et al. (2014) Interrelationships between maternal DHA in erythrocytes, milk and adipose tissue. Is $1 \mathrm{wt} \%$ DHA the optimal human milk content? Data from four Tanzanian tribes differing in lifetime stable intakes of fish. BrJ Nutr 111, 854-866.

24. Luxwolda MF, Kuipers RS, Kema IP, et al. (2013) Vitamin D status indicators in indigenous populations in East Africa. Eur J Nutr 52, 1115-1125.

25. Ho-Pham LT, Nguyen ND, Lai TQ, et al. (2011) Vitamin D status and parathyroid hormone in a urban population in Vietnam. Osteoporos Int 22, 241-248.

26. Nguyen HT, von Schoultz B, Nguyen TV, et al. (2012) Vitamin $\mathrm{D}$ deficiency in northern Vietnam: prevalence, risk factors and associations with bone mineral density. Bone 51, 1029-1034.

27. Corso G, Rossi M, De BD, et al. (2002) Effects of sample storage on 7- and 8-dehydrocholesterol levels analysed on whole blood spots by gas chromatography-mass spectrometry-selected ion monitoring. J Chromatogr B Analyt Technol Biomed Life Sci 766, 365-370. 
28. Kamao M, Tsugawa N, Suhara Y, et al. (2007) Quantification of fat-soluble vitamins in human breast milk by liquid chromatography-tandem mass spectrometry. J Chromatogr B Analyt Technol Biomed Life Sci 859, 192-200.

29. Volmer M, Meiborg G \& Muskiet FA (1988) Simultaneous capillary gas chromatographic profiling of medium-and longchain fatty acid methyl esters with split injection. Correction for injection-related discrimination by the 'bracketing' method. J Chromatogr 434, 385-394.

30. van der Steege G, Muskiet FA, Martini IA, et al. (1987) Simultaneous quantification of total medium- and long-chain fatty acids in human milk by capillary gas chromatography with split injection. J Chromatogr 415, 1-11.

31. Henry HL, Bouillon R, Norman AW, et al. (2010) 14th Vitamin D Workshop consensus on vitamin D nutritional guidelines. J Steroid Biochem Mol Biol 121, 4-6.

32. Zittermann A (2003) Vitamin D in preventive medicine: are we ignoring the evidence? Br J Nutr 89, 552-572.

33. Chaplin G \& Jablonski NG (2009) Vitamin D and the evolution of human depigmentation. Am J Phys Anthropol 139, 451-461.

34. Greer FR, Hollis BW, Cripps DJ, et al. (1984) Effects of maternal ultraviolet $\mathrm{B}$ irradiation on vitamin $\mathrm{D}$ content of human milk. J Pediatr 105, 431-433.

35. Wagner CL, Hulsey TC, Fanning D, et al. (2006) High-dose vitamin $\mathrm{D}_{3}$ supplementation in a cohort of breastfeeding mothers and their infants: a 6-month follow-up pilot study. Breastfeed Med 1, 59-70.

36. Hollis BW, Wagner CL, Howard CR, et al. (2015) Maternal versus infant vitamin D supplementation during lactation: a randomized controlled trial. Pediatrics 136, 625-634.

37. European Food Safety Authority (2012) Scientific opinion of the NDA panel: tolerable upper intake level of vitamin D. http:// www.efsa.europa.eu/en/efsajournal/pub/2813.htm （accessed May 2014).

38. Sioen I, De Henauw S, Van Camp J, et al. (2009) Comparison of the nutritional-toxicological conflict related to seafood consumption in different regions worldwide. Regul Toxicol Pharmacol 55, 219-228.

39. Brouwer DA, van Beek J, Ferwerda H, et al. (1998) Rat adipose tissue rapidly accumulates and slowly releases an orallyadministered high vitamin D dose. BrJ Nutr 79, 527-532.
40. Didriksen A, Burild A, Jakobsen J, et al. (2015) Vitamin $\mathrm{D}_{3}$ increases in abdominal subcutaneous fat tissue after supplementation with vitamin $\mathrm{D}_{3}$. Eur $J$ Endocrinol $\mathbf{1 7 2}$, 235-241.

41. Snijder MB, van Dam RM, Visser M, et al. (2005) Adiposity in relation to vitamin D status and parathyroid hormone levels: a population-based study in older men and women. J Clin Endocrinol Metab 90, 4119-4123.

42. Dent CE \& Gupta MM (1975) Plasma 25-hydroxyvitamin-Dlevels during pregnancy in Caucasians and in vegetarian and non-vegetarian Asians. Lancet ii, 1057-1060.

43. Hillman LS, Slatopolsky E \& Haddad JG (1978) Perinatal vitamin D metabolism. IV. Maternal and cord serum 24, 25-dihydroxyvitamin D concentrations. J Clin Endocrinol Metab 47, 1073-1077.

44. Salle BL, Delvin EE, Lapillonne A, et al. (2000) Perinatal metabolism of vitamin D. Am J Clin Nutr 71, 5 Suppl., 1317S-1324S.

45. Abboud M, Rybchyn MS, Rizk R, et al. (2017) Sunlight exposure is just one of the factors which influence vitamin D status. Photochem Photobiol Sci 16, 302-313.

46. Heaney RP, Horst RL, Cullen DM, et al. (2009) Vitamin $\mathrm{D}_{3}$ distribution and status in the body. J Am Coll Nutr $\mathbf{2 8}$, 252-256.

47. Hadden DR \& McLaughlin C (2009) Normal and abnormal maternal metabolism during pregnancy. Semin Fetal Neonatal Med 14, 66-71.

48. Cooke NE \& Haddad JG (1989) Vitamin D binding protein (Gc-globulin). Endocr Rev 10, 294-307.

49. Hollis BW \& Wagner CL (2013) Clinical review: the role of the parent compound vitamin $\mathrm{D}$ with respect to metabolism and function: why clinical dose intervals can affect clinical outcomes. J Clin Endocrinol Metab 98, 4619-4628.

50. Kuipers RS, Luxwolda MF, Offringa PJ, et al. (2012) Gestational age dependent content, composition and intrauterine accretion rates of fatty acids in fetal white adipose tissue. Prostaglandins Leukot Essent Fatty Acids 86, 39-49.

51. Ziegler EE, Nelson SE \& Jeter JM (2014) Iron stores of breastfed infants during the first year of life. Nutrients $\mathbf{6}$, 2023-2034. 